\title{
Effectiveness of AIDS education program on nursing students' AIDS knowledge and AIDS attitudes in Sri Lanka
}

\author{
Geethika N. Nanayakkara*1,2, Eun-Ok Choi ${ }^{2}$ \\ ${ }^{1}$ National School of Nursing, Sri Jayawardenapura, Thalapathpitiya, Nugegode, Sri Lanka \\ ${ }^{2}$ Department of Nursing, Inje University, Republic of Korea
}

Received: August 12, 2017

Accepted: December 7, 2017

Online Published: December 18, 2017

DOI: $10.5430 /$ jnep.v8n6p1

URL: https://doi.org/10.5430/jnep.v8n6p1

\begin{abstract}
Stigmatization and discrimination of HIV/AIDS patients is an important issue specially in caring institutions. This would be minimized, among nurses who play a major role in these institutions, by improving AIDS knowledge and AIDS attitude. This study was conducted to assess the effectiveness of an AIDS education program on trainee nurses' AIDS knowledge and AIDS attitudes. Randomized controlled, pretest post-test study was carried out on students in National School of Nursing, Sri Lanka. All participants, experimental group $(\mathrm{N}=65)$ and control group $(\mathrm{N}=64)$, completed a self-administered instruments of HIV/AIDS knowledge scale and a AIDS attitudes scale at pre-test and post-test point. A focused AIDS education program was conducted for the experimental group. Differences in AIDS knowledge and attitudes, as evident by the differences in answers for pretest and post-test, in the two groups were compared. Data was analyzed using Statistical Package for the Social Sciences for WIN 18.0. Both AIDS knowledge $(p<.001)$ and AIDS attitudes $(p<.001)$ of the student nurses improved significantly after the intervention. Sub-dimensions of HIV/AIDS knowledge scale, namely HIV course and manifestations $(t=-6.84, p<.001)$, HIV transmission $(t=-7.28 .44, p<.001)$, occupational risk of HIV and prevention $(t=-10.59, p<.001)$ and management of HIV and anti-retroviral treatment $(t=-12.81, p<.001)$ all showed significant improvement in the experimental group. Sub-dimensions of AIDS attitude scale, namely blame and judgment $(t=-3.35, p=.001)$, attitudes towards imposed measures $(t=-5.44, p<.001)$ and attitudes in comfortable in dealing with a HIV/AIDS patients $(t=-4.25, p<.001)$ also showed significant improvement. This AIDS Education Program showed statistically significant improvement in the AIDS knowledge and AIDS attitudes of student nurses and its usefulness in reducing stigma and discrimination of People Living with HIV and its potential for future use in Sri Lanka and other countries with similar background.
\end{abstract}

Key Words: HIV/AIDS, Knowledge, Attitudes, AIDS education program, Nursing students

\section{INTRODUCTION}

Nurses play an important role ${ }^{[1]}$ in prevention of HIV by providing care and treatment for people living with HIV/AIDS (PLHIV). Therefore, nurses should be competent in caring and solving health problems of PLHIV. But research shows that nurses are having negative attitudes and weak knowledge $^{[2]}$ on HIV/AIDS, and hesitancy to care for PLHIV. ${ }^{[3]}$ This has caused poor quality of nursing care as well as discrimination and stigmatization against PLHIV. ${ }^{[4]}$ Furthermore, though, nurses are doing daily nursing care and treat-

\footnotetext{
*Correspondence: Geethika N. Nanayakkara; Email: ngeethika@yahoo.com; Address: National School of Nursing, Sri Jayawardenapura, Thalapathpitiya, Nugegode, Sri Lanka.
} 
ments for PLHIV, nurses have difficulty in updating their knowledge. ${ }^{[5]}$ Nursing students' attitudes of caring PLHIV is very important as they will be the nurses in future. ${ }^{[6,7]}$

Research from Canada ${ }^{[8]}$ and Sri Lanka ${ }^{[9,10]}$ indicated that PLHIV are suffering stigma and discrimination in health care settings which were generally associated with poor knowledge and attitudes about HIV/AIDS of practicing nurses. ${ }^{[9,10]}$ Some previous studies have shown that knowledge alone is not adequate to provide empathetic care to PLHIV ${ }^{[11]}$ while others show that students' attitudes toward HIV/AIDS improved with by the increase in the knowledge. ${ }^{[12]}$ HIV/AIDS training programs or lectures about HIV/AIDS can help students to practice good HIV/AIDS preventive behavior. El-nandy et al. ${ }^{[13]}$ revealed a positive correlation between student nurses knowledge and attitudes towards PLHIV.

Nurses' negative attitudes and unwillingness to provide care to people with HIV and AIDS is an important reason for a poorer quality care. ${ }^{[7]}$ The quality of the care delivered by a nurse relates directly to her basic nursing education. ${ }^{[8]}$ Practice based HIV/AIDS education is important for students during their clinical training as it provides a chance to learn measures need to be taken to protect self and others from HIV contagion. ${ }^{[14]}$ Student with more experience have more positive attitudes than who have not. ${ }^{[15]}$ McCarthy et al. ${ }^{[16]}$ showed health care workers need HIV training and education to give high quality care.

This study was developed aiming to assess the impact of an AIDS Education Program on the AIDS knowledge and AIDS attitudes of student nurses. The Educational Program was aimed to improve student nurses' AIDS knowledge and correct erroneous AIDS attitudes. Worthy AIDS knowledge and correction of incorrect attitudes towards AIDS will eventually result in a higher quality compassionate nursing care for people with HIV and AIDS. ${ }^{[7]}$ Inadequate knowledge about the disease was the reason for health care workers' negative attitudes and discriminatory behaviors towards PLHIV. ${ }^{[17-19]}$ It is very important that nurses be educationally prepared to give safe, skilled and systematic care for patients irrespective of their diagnosis. ${ }^{[15]}$ Knowledge of AIDS, especially knowledge on the mode of transmission to relieve the fear of caring for PLHIV, ${ }^{[20]}$ will lead to improvement in the care.

However, previous research revealed that a large number of nursing students and nurses think nurses should have the right to refuse the care of HIV patients. ${ }^{[21,22]}$ To overcome this erroneous belief, nursing students need to be prepared to practice in a safe and competent manner to provide care for PLHIV. ${ }^{[15]}$ Nurses and nursing students have a moral and ethical responsibility to care for communities with or without AIDS or other diseases. ${ }^{[23]}$ Nursing students need guided experiences ${ }^{[24]}$ and correct information through effective educational techniques to increase the knowledge and to develop positive attitudes towards AIDS. ${ }^{[25]}$ Because of this, new information about AIDS should be included in nursing curricula. ${ }^{[8,23]}$ At present, this is not so with the curriculum of student nurses in Sri Lanka. Therefore, it is important to see the effectiveness of AIDS education program on student nurses' AIDS knowledge and AIDS attitudes in Sri Lanka.

\section{METHODS}

\subsection{Research design and setting}

An experimental control group pretest-posttest design with random assignment technique was utilized at National school of nursing Sri Lanka.

\subsection{Participants}

The numbers of participants were calculated by using $\mathrm{G}$ power analysis 3.1. At least 102 participants (51 per group) were needed to perform for one tail analysis given as medium effect size of 0.5 , power of 0.8 , and a $p$ value of .05 . Considering the possibility of drop-outs a full batch of second year nursing students comprising of 129 students were recruited for this study. All 129 students of the batch consented to participate in the study and completed pre and post-tests.

\subsection{Development of the AIDS education program}

AIDS Educational Program consisted of six sessions (two hours each) of 12 lecture hours (see Table 1). Teaching strategies included series of lectures, small group discussions, group activities and testimony of PLHIV. These testimonies were presented live by two PLHIV followed by discussions with them. These sessions were organized focusing students active group participations. The content of the AIDS Education Program were identified and developed based on findings from previously used AIDS education programs for health care workers ${ }^{[26-34]}$ and with guidance of HIV professionals in Sri Lanka. Resource personal used educational materials such as visual materials, case scenario and printed materials.

Participants of this study, being second year nursing students, were thought to have the ability to process and discuss relevant information. The case scenario strategy, based on true case histories, used in this program was expected to contribute to the students' ability to process the information.

Testimony of PLHIV was conducted by two HIV positive women where all of experimental group participated as small groups taking turns. They described the stigma and discrimination they had experienced and how they were living positively with the disease. Researcher was expecting that the familiarity with HIV positive women and discussion with 
them would be highly effective in reducing nursing students' stigmatizing attitudes and fear of contagion. Researcher also expected that it would enhance students' emotional competence to treat PLHIV. A HIV care nurse delivered a lecture and discussed issues in nursing care of PLHIV. Researcher was expecting that this would be very relevant to student nurses because the HIV care nurse has current knowledge, more skills and experience than other nurses. She also has sympathetic feelings towards PLHIV. She would be also aware of practical issues which arise during care of these patients. A HIV physician discussed the natural history, pathophysiology and clinical presentation of HIV/AIDS. Another HIV physician discussed the post exposure prophylaxis and prevention of needle stick injuries. A medical officer of venereology discussed the anti-retroviral treatment and follow up of PLHIV. Small group discussions regarding stigma and discrimination were done by HIV physician, medical officer and a HIV nurse using case scenarios based on actual case histories (see Table 1).

Table 1. AIDS Education Program including student centered learning activity ( 6 sessions), 4 hours/ day. Target group: 2nd year nursing students (for experimental group). Total lecture hours: 12

\begin{tabular}{|c|c|c|c|c|c|}
\hline Session & $\begin{array}{l}\text { Lecture } \\
\text { hours }\end{array}$ & Contents & Competencies & $\begin{array}{l}\text { Resource person/ } \\
\text { Lecturer/Facilitator }\end{array}$ & $\begin{array}{l}\text { Teaching strategies/ } \\
\text { learning activities }\end{array}$ \\
\hline 1 & 2 & $\begin{array}{l}\text { HIV \& AIDS Epidemiology. } \\
\text { Natural history \& pathophysiology of } \\
\text { HIV infection. } \\
\text { Clinical presentation of HIV patient. } \\
\text { Diagnosis and clinical management. }\end{array}$ & knowledge & $\begin{array}{l}\text { Physician } \\
\text { (HIV care specialist ) }\end{array}$ & $\begin{array}{l}\text { Lecture/discussions, } \\
\text { and visual material. } \\
\text { Case scenario }\end{array}$ \\
\hline 2 & 2 & $\begin{array}{l}\text { Anti-retroviral (ARV) therapy } \\
\text {-How ARV drugs work. } \\
\text {-Assessing patient’s response to ARV. } \\
\text {-Importance of adherence. } \\
\text {-Mother to child transmission } \\
\text {-Prevention strategy. }\end{array}$ & $\begin{array}{l}\text { knowledge \& } \\
\text { skills }\end{array}$ & $\begin{array}{l}\text { Medical doctor in } \\
\text { Venereology }\end{array}$ & $\begin{array}{l}\text { Lecture/discussion and } \\
\text { visual material. }\end{array}$ \\
\hline 3 & 2 & $\begin{array}{l}\text { Methods of HIV transmission \& } \\
\text { non-transmission. } \\
\text {-How to practice standard precautions. } \\
\text {-Post exposer prophylaxis. }\end{array}$ & $\begin{array}{l}\text { Knowledge \& } \\
\text { skills }\end{array}$ & $\begin{array}{l}\text { Physician } \\
\text { (HIV care specialist) }\end{array}$ & $\begin{array}{l}\text { Small group } \\
\text { discussion \& } \\
\text { Case scenario }\end{array}$ \\
\hline 4 & 2 & $\begin{array}{l}\text { Nursing management and issues of } \\
\text { HIV/AIDS in the hospital and in the } \\
\text { community. }\end{array}$ & $\begin{array}{l}\text { Knowledge, } \\
\text { skills \& } \\
\text { attitudes. }\end{array}$ & $\begin{array}{l}\text { HIV care } \\
\text { nurse/Researcher }\end{array}$ & Lecture /discussion \\
\hline 5 & 2 & $\begin{array}{l}\text { HIV related Stigma. } \\
\text { Stigmatization and discrimination. } \\
\text { Impact of stigmatization on the quality } \\
\text { of life. }\end{array}$ & $\begin{array}{l}\text { Knowledge } \\
\text { and attitudes. } \\
\text { Stigma } \\
\text { reduces. }\end{array}$ & $\begin{array}{l}\text { Team teaching. } \\
\text { (Medical officer, HIV } \\
\text { care nurse, Physician) }\end{array}$ & $\begin{array}{l}\text { Small group activity. } \\
\text { Discussion of case } \\
\text { scenarios }\end{array}$ \\
\hline 6 & 2 & $\begin{array}{l}\text { Testimonials of people living with HIV } \\
\text { (PLHIV). }\end{array}$ & $\begin{array}{l}\text { Attitude \& } \\
\text { reduce stigma. }\end{array}$ & $\begin{array}{l}\text { Two people living } \\
\text { with HIV }\end{array}$ & $\begin{array}{l}\text { Small Group } \\
\text { discussion }\end{array}$ \\
\hline
\end{tabular}

\subsection{Measurement scales}

The measurement scales were designed with structured closeended, multiple-choice questions except for one open-ended question about the age of the respondent.

The HIV/AIDS knowledge scale was based on an instrument developed by Eckstein ${ }^{[35]}$ to measure the knowledge of nurses towards patients infected with HIV/AIDS. This scale has been used in previous studies in South Africa, ${ }^{[36]}$ Jordan, ${ }^{[2]}$ and Saudi Arabia. ${ }^{[37]}$ Further 10 items were added to the scale to improve the assessment of this program outcome. This scale was divided into four domains to give more clarity

Published by Sciedu Press to the assessment: course and manifestations of HIV/AIDS, HIV transmission, occupational risk of HIV and prevention and management of HIV including antiretroviral treatment (see Table 2).

For AIDS knowledge scale, each correct response was given a score of 1 whiles an incorrect or don't know response was given a score of 0 . Total knowledge score can range between 0-38. HIV/AIDS knowledge scale of Eckstein ${ }^{[35]}$ had been already validated and had Cronbach $\alpha$ coefficient of 0.67 . In this study Cronbach $\alpha$ coefficient is 0.82 . 
Generic AIDS attitudes scale (GAAS) developed by Froman and Owen ${ }^{[38]}$ was used to measure attitudes. The AIDS attitude scale has been used for studies in many countries including India ${ }^{[39]}$ and South Africa. ${ }^{[36]}$ Majority of studies used this to assess nursing students and working nurses. ${ }^{[40]}$ According to Froman and Owen ${ }^{[41]}$ this instrument was developed for the purpose of using among nursing students and other health care personnel to evaluate changes in attitudes towards people with HIV/AIDS. The attitudes part of the questionnaire contains 21 items which are valued on a six point scale where 0 is 'strongly disagree' and 5 is 'strongly agree'. Positive attitude items were coded with "strongly disagree $=0$ " to "strongly agree $=5$ " and negative attitude items are coded in the reverse manner. In this study 20 items were used from AIDS attitude scale. Item number 20 of the original scale was removed from the scale of the study as all study participants were unmarried. Score ranges from 0 to 100 and higher scores indicate more agreement.

Attitude scale was divided into three domains (see Table 2 ). Those are attitudes of blame and judgement (7 items), attitudes on HIV towards imposed measures (7 items) and attitudes of comfortable in dealing with HIV/AIDS patients (6 items).

Questionnaires were reviewed and confirmed for content validity and clarified for the content of AIDS knowledge scale by HIV care physician, HIV care nurse and a PLHIV. Content validity index (CVI) was 1 .

\subsection{Ethics and Data collection procedure}

This study was reviewed and approved by the Inje University Institutional Review Board (IRB No: 20141211-HR-127) in Republic of Korea, and by the Ethical Review Committee of the Faculty of Medicine, University of Colombo, Sri Lanka (EC-15-015). All the ethical standards of the research were followed: anonymity, voluntary participation, and the right to refuse to participate were guaranteed to respondents Consent was obtained in a written form.

One hundred and twenty nine students were enrolled in the study and all of them completed the self-reported structured questionnaire which included general characteristics, HIV/AIDS knowledge scale and Generic AIDS attitude scale. Then they were randomly assigned into two groups i.e. the control group $(\mathrm{N}=64)$ and the experimental group $(\mathrm{N}=$ 65). AIDS education program was conducted for the experimental group while the control group was attending to their usual study program. Two weeks after the AIDS Education Program for experimental group, post-test was held for all the participants of control and experimental groups. Data was collected at pre-test point and post-test point.

4

\subsection{Data analysis}

Statistical analyses were performed using the Statistical Package for Social Science (SPSS) for WIN 18.0. The independent $t$-test was used to compare the means of knowledge in the pre and post-tests between groups. The paired $t$-test was used to compare the means of knowledge in the pre and post-test within groups. The independent $t$-test analysis was used to compare the two groups with regard to demographic characteristics and to compare pre-test scores of independent values for homogeneity test. Statistical significance was set at $p<.05$ (95\% confidence interval).

\section{RESULTS}

\subsection{Equivalence of the participants}

\subsubsection{General characteristics and homogeneity}

There were 129 nursing students participated in the study. The mean age of the experimental group was 22.89 (1.10) year and that of control group was 23.19 (1.28) year. Age range was between 20 and 26. All the participants were females $(\mathrm{N}=129,100 \%)$ and all were in same school year.

\subsubsection{Homogeneity of dependent variables}

The results of the $t$-test analysis of the pretest indicated that experimental and control groups did not differ significantly on AIDS knowledge and AIDS attitudes. AIDS knowledge scores of the experimental and control groups were 18.03 (3.84) and 16.84 (4.08) respectively. Mean scores of the AIDS attitudes for experimental and control groups were 64.88 (11.13) and 64.25 (10.05) respectively. At the pretest point, there were no statistically significant differences in AIDS knowledge $(t=1.7, p=.92)$ and AIDS attitudes $(t=$ $.34, p=.738$ ) between the two groups. In addition, all the subdimensions of the AIDS knowledge scale and AIDS attitudes scale were compared. There was no significant difference in sub-dimensions of both the knowledge and attitudes at pretest point (see Table 2).

\subsection{AIDS knowledge}

AIDS knowledge of the experimental group improved significantly after the intervention when compared to its preintervention knowledge as well as when compared to the control group. The pretest knowledge score of the experimental group was 18.03 (3.84) and this improved to 26.97 (3.68) after the education program. The pretest and posttest scores of the control group were 16.84 (4.08) and 15.78 (4.05) respectively.

\subsubsection{Sub-dimension 1: Course and manifestations}

Knowledge on HIV course and manifestations score of the control group was 2.89 (3.01) in the pre-test, and 4.27 (2.33) in post-test respectively. The mean pre-test score of the experimental group was 3.12 (3.06), whereas the mean post-test 
score was 7.31 (1.70). There was a statistically significant cally significant difference between experimental and control difference between HIV knowledge scale in the experimental groups for knowledge of HIV course and manifestations was group pre and post-test $(p<.001$, paired $t$-test). A statisti- found at the post-test $(t=8.49, p<.001)$ (see Table 3 ).

Table 2. Homogeneity test results between two groups $(\mathrm{N}=129)$

\begin{tabular}{|c|c|c|c|c|}
\hline \multirow{2}{*}{$\begin{array}{l}\text { Variables or AIDS knowledge sub-dimensions or AIDS attitudes } \\
\text { sub-dimensions }\end{array}$} & $\begin{array}{l}\text { Experimental Group } \\
(N=65)\end{array}$ & $\begin{array}{l}\text { Control group } \\
(N=64)\end{array}$ & \multirow[t]{2}{*}{$t$} & \multirow[t]{2}{*}{$p$} \\
\hline & Mean (SD) & Mean (SD) & & \\
\hline Age & $22.89(1.10)$ & $23.19(1.28)$ & -1.42 & .160 \\
\hline AIDS Knowledge & $18.03(3.84)$ & $16.84(4.08)$ & 1.70 & .092 \\
\hline HIV course \& manifestation & $3.12(3.06)$ & $2.89(3.01)$ & 0.28 & .417 \\
\hline HIV transmission & $6.69(1.55)$ & $6.53(1.50)$ & 0.60 & .550 \\
\hline Occupational risk of HIV prevention & $4.60(1.55)$ & $4.58(1.40)$ & 0.08 & .933 \\
\hline Management of HIV \& Antiretroviral treatment & $1.37(1.36)$ & $1.34(1.42)$ & 0.10 & .917 \\
\hline AIDS Attitudes & $64.88(11.13)$ & $64.25(10.05)$ & 0.34 & .738 \\
\hline Attitude toward blamed \&Judgment & $17.02(5.50)$ & $16.92(6.26)$ & 0.09 & .928 \\
\hline Attitude towards imposed measures & $25.49(5.01)$ & $25.38(5.38)$ & 0.13 & .898 \\
\hline Attitude towards comfortable in dealing with a HIV/AIDS patient & $22.37(4.41)$ & 21.95 (4.13) & 0.55 & .581 \\
\hline
\end{tabular}

\subsubsection{Sub-dimension 2: HIV transmission}

There was a statistically significant increase in students' knowledge on transmission of HIV following the AIDS educational program in the experimental group $(p<.001$, paired $t$-test). While the control group showed a reduction of score from pretest $(6.53 \pm 1.50)$ to post-test $(5.69 \pm 1.48)$, the post-test score of knowledge about HIV transmissions of the experimental group increased from the pretest score of 6.69 (1.55) to 8.22 (1.23).

The mean post-test score of the experimental group was higher than that of control group and this difference was statistically significant $(t=10.60, p<.001)$ (see Table 3$)$.

\subsubsection{Sub-dimension 3: Occupational risk of HIV and pre- vention}

In the comparison between two groups regarding knowledge of occupational risk of HIV and prevention, experimental group has shown a statistically significant improvement after AIDS education program $(p<.001$, paired $t$-test). Pretest mean score of the experimental group and control group were 4.60 (1.55) and 4.58 (1.41) respectively. The mean post-test score of the experimental group was 7.15 (1.54) and the post-test score for control group was 4.57 (1.49).

The difference in post-test results between the experimental and control groups was statistically significant $(t=9.63, p<$ .001) (see Table 3).

\subsubsection{Sub-dimension 4: Management of HIV and anti- retroviral treatment}

After the education program, there was a statistically significant improvement in the knowledge about management of HIV and antiretroviral treatment in the experimental group
( $p<.001$, paired $t$-test). The pre-education mean score was 1.37 (1.36), whereas the mean post education score was 4.29 (1.37). Among the control group students, the mean pre-education score was 1.34 (1.42) whereas the mean posteducation score was 1.25 (1.22).

Both control and the experimental group were compared for difference in mean score at the post-test. This difference was statistically significant $(t=13.32, p<.001)$ (see Table 3$)$.

\subsection{AIDS attitudes}

AIDS attitudes of the experimental group improved significantly after the intervention when compared to its preintervention attitudes as well as when compared to the control group. The pretest attitude score of the experimental group was 64.88 (11.13) and this improved to 73.82 (9.66) after the education program. The pretest and posttest scores of the control group were 64.25 (10.05) and 61.41(11.33) respectively.

\subsubsection{Sub-dimension 1: Attitudes of blame and judgment}

Significant differences were found on student nurses' AIDS attitudes of blame and judgment towards patients with HIV/AIDS at pre and post-test in experimental group ( $p$ $=.001$, paired $t$-test). The pre-education mean score of AIDS attitudes of blame and judgment was 17.02 (5.50), whereas the mean post-education knowledge score was 19.94 (5.61) in experimental group. Among the control group students, the mean pre-education attitudes score was 16.92 (6.26), whereas the mean post-education attitude score was 17.55 (4.76).

The mean post-test score of the experimental group was 
higher than that of control group and this difference was 3 ). statistically significant $(t=2.61, p=.01)$ (see Table 3$)$.

\subsubsection{Sub-dimension 2: Attitudes towards imposed mea- sures}

The assessment at pre and post-test for attitudes towards imposed measures has shown a significant difference in experimental group ( $p<.001$, paired $t$-test). The mean preeducation attitudes score was 25.49 (5.01), whereas the mean post-education score was 29.28 (4.30). In the control group mean score of the post-test was 23.09 (5.62) even lower than the pre-test mark of 25.38 (5.38).

When the control group and the experimental groups were compared at post-test, the difference of HIV attitudes scale in imposed measures between experimental and control groups were statistically significant $(t=7.02, p<.001)$ (see Table

\subsubsection{Sub-dimension 3: Comfortable in dealing with a HIV/AIDS patient}

The mean pre-education score of attitudes towards comfortable in dealing with a HIV/AIDS patient in the experimental group was 22.37 (4.40), whereas the mean post-education score was 24.60 (3.59). This change was statistically significant ( $p<.001$, paired $t$-test). The mean pre-test attitude level in control group was 21.95(4.13), whereas the mean post-test score was 20.77 (5.20) and was not statistically significant $(p=.134$, paired $t$-test).

The post-test difference in mean scores between both experimental and control group was statistically significant $(t=$ $4.88, p<.001$ ) (see Table 3).

Table 3. Effects on AIDS education program $(\mathrm{N}=129)$

\begin{tabular}{|c|c|c|c|c|c|}
\hline \multirow[t]{2}{*}{ Outcome variables } & $\begin{array}{l}\text { Experimental } \\
(N=65)\end{array}$ & $\begin{array}{l}\text { Control } \\
(N=64)\end{array}$ & \multirow{2}{*}{$\begin{array}{l}\text { Mean } \\
\text { Difference }\end{array}$} & \multirow[t]{2}{*}{$t$} & \multirow[t]{2}{*}{$p$} \\
\hline & Mean ( SD) & Mean (SD) & & & \\
\hline AIDS Knowledge & 26.97 (3.68) & $15.78(4.05)$ & 11.19 & 16.35 & $<.001$ \\
\hline Course \& manifestations & $7.31(1.70)$ & $4.27(2.33)$ & 3.04 & 8.49 & $<.001$ \\
\hline Transmission & $8.22(1.23)$ & $5.69(1.48)$ & 2.53 & 10.60 & $<.001$ \\
\hline Occupational risk \& prevention & $7.15(1.54)$ & $4.57(1.49)$ & 2.58 & 9.63 & $<.001$ \\
\hline Management of HIV \& ART & $4.29(1.37)$ & $1.25(1.22)$ & 3.04 & 13.32 & $<.001$ \\
\hline AIDS attitudes & $73.82(9.66)$ & $61.41(11.33)$ & 12.41 & 6.70 & $<.001$ \\
\hline Blame and judgment & $19.94(5.61)$ & 17.55 (4.76) & 3.39 & 2.61 & .010 \\
\hline Attitudes towards imposed measures & $29.28(4.30)$ & $23.09(5.62)$ & 6.18 & 7.02 & $<.001$ \\
\hline Comfortable in dealing with a HIV/AIDS patient & 24.60 (3.59) & 20.77 (5.19) & 3.83 & 4.88 & $<.001$ \\
\hline
\end{tabular}

\section{Discussion}

Findings of previous research, which showed inadequate AIDS knowledge and poor AIDS attitude of practicing nurses in Sri Lanka, highlighted the importance of undergraduate training focusing on competent AIDS nursing care. ${ }^{[9,10]}$ Purpose of this experimental control group pretest post-test random assigning study was multi-dimensional. Firstly, it was to assess the current AIDS knowledge and AIDS attitudes of second year student nurses; secondly, to conduct a AIDS education program and thirdly to evaluate the outcome of the program.

Expected outcome competency of this AIDS Education Program is similar to the HIV competency framework of Canadian Association of Nurses in AIDS Care (CANAC). ${ }^{[42]}$ CANAC framework is aimed at new nursing students in Canada and is focused to prepare a nurse to deliver a competent care to PLHIV.
Findings of this study have shown the need of a proper and focused AIDS education for nursing students. Undergraduate nursing education in Sri Lanka is a three year comprehensive training program. However, content it has on HIV/AIDS is minimum. This AIDS Education Program identified a need to review nursing curriculum in Sri Lanka to facilitate and increase students' capacity in providing a competent care to PLHIV by improving their AIDS knowledge and AIDS attitudes.

Sri Lanka is a low prevalent country for HIV. ${ }^{[43]}$ Therefore, the chances of encountering PLHIVs are less for a student nurse during their training. The inadequacy of proper education regarding HIV/AIDS has affected Jordanian nurses to depend on informal channel such as Internet, newspapers, friends etc. These supposed to be the factors for Jordanian nurses to have an inadequate and incorrect understanding of HIV/AIDS. A negative attitude toward PLHIV and weak knowledge level was resulted from this. ${ }^{[2]}$ This shows the 
necessity of having proper information for health care workers. It is vital to have accurate information on HIVAIDS so that undue fear can be minimized while strengthening the measures for prevention.

This study provided opportunity for student nurses for active learning. Face to face communication with PLHIV was a novel experience giving them the opportunity to have firsthand information. Furthermore, such an encounter would be beneficial to relieve fear and misconceptions towards PLHIV. Similar results were reported by Yiu et al. ${ }^{[34]}$ Also this would give an opportunity to understand the problems faced by PLHIV and possible results of those. Furthermore, this program enabled student nurses to learn from HIV specialists: a HIV physician and a HIV nurse, and to acquire proper knowledge.

Improved AIDS knowledge through this education program will enable them to take necessary precautions in their nursing practice to protect them from blood borne diseases, without discriminating PLHIV. Therefore, this study provides strong evidence that improved knowledge and attitudes would improve student nurses' competency in serving PLHIV thereby contributing to prevention of spread of HIV in the community.

Effectiveness of this program was shown by statistically significant improvement of AIDS knowledge $(p<.001)$ and AIDS attitudes $(p<.001)$ of post-test results of the experimental group. The experimental group had higher post-test scores on AIDS knowledge and AIDS attitudes compared to the control group which were statistically significant.

There were researches reporting consisting result with this study showing effectiveness of education program in AIDS knowledge ${ }^{[44-46]}$ and AIDS attitudes ${ }^{[37]}$ or both. ${ }^{[42]}$ Dixit et al. ${ }^{[45]}$ conducted a study to assess the impact of educational intervention measures on knowledge regarding HIV/ occupational exposure and post exposure prophylaxis (PEP) among final year nursing students of a Tertiary Care Hospital in Central India. This showed a statistically significant improvement in the knowledge on HIV after the intervention by increasing post-test mean score from 24 percent than pretest mean score. Sabane et al. ${ }^{[4]}$ showed statistically significant improvement in AIDS knowledge of nursing students after education on knowledge about post exposure prophylaxis. They found mean scores in section of facts about HIV increased from .82 to 5.70 , and prevention of HIV from - .25 to 3.67 and knowledge of post exposer prophylaxis from 1.05 to 4.40. A study conducted ${ }^{[46]}$ in Cairo University, Egypt showed a significant improvement in the general knowledge about HIV/AIDS in two nursing groups (undergraduate and post graduate) after a health education intervention program. Pre intervention mean score was 7.29 and post intervention mean score was 8.01. Gutierrz ${ }^{[37]}$ showed significant improvement on attitudes towards HIV/AIDS after education intervention on stigma reduction among nurses. The results indicated a statistically significant difference between pre and post-test results $(p=.044)$. Angel Rajakumari and Sheela ${ }^{[47]}$ showed significant improvement on AIDS knowledge and AIDS attitudes after an educational intervention for nursing students. Their study AIDS knowledge mean score increased from 7.68 to 20.21 and AIDS attitude mean score increased from 10.48 to 15.38 .

\section{CONCLUSIONS AND RECOMMENDATIONS}

This study provides a unique opportunity in evaluating the effects of AIDS education program among second year nursing students in Sri Lanka. The researcher analyzed the effectiveness of AIDS education program among nursing students' competence of AIDS knowledge and AIDS attitudes towards PLHIV. Results have shown significant improvement in both competencies; AIDS knowledge and AIDS attitudes, after intervening with AIDS education program. Results suggest that a structured program with the participation of expert professionals and PLHIV as resource personal and using active learning strategies significantly improved the AIDS knowledge and AIDS attitudes to acquire competences of AIDS nursing care.

\subsection{Usefulness and further suggestions}

Good knowledge and correct attitude of HIV/AIDS of nurses is an essential component in reducing stigma and discrimination of PLHIV in health care settings. Therefore, a structured and focused education program for student nurses is essential. Furthermore, this will enable nurses to take necessary preventive measures from occupational risks without discriminating PLHIV. Minimizing discrimination and stigmatization would help in reducing the spread of the illness. Therefore, we suggest structured and focused programs of this nature to be included in the curriculum of student nurses'.

\subsection{Study limitations}

(1) PLHIV participated in this were persons who had experience in participating in education programs. Involving such persons for educational programs in all the nursing training schools would be practically difficult.

(2) As HIV is still low prevalent in Sri Lanka, clinicians and nurses specialized in HIV are very few. Although their services were obtained for this educational program, it would not be possible to get their services to all nursing training schools across the country.

(3) The alternative to the above limitations would be to have trainers trained on those aspects. However, such persons will not have same experience; therefore, can 
be less effective as resource personals participated in this study.

\section{CONFliCtS OF INTEREST Disclosure}

The authors declare that there is no conflict of interest.

\section{REFERENCES}

[1] Mockiene V, Suominen T, Valimaki M, et al. Impact of intervention Programs on nurses' Knowledge, attitudes, and willingness to take care of patients with human immunodeficiency virus/acquired immunodeficiency syndrome: a descriptive review.Medicine(Kaunas) [Internet]. 2010; 46(3): 159-68. Availabl from: http://medicina .1smuni.1t/med/1003/100301e.htm

[2] Hassan ZM, Wahsheh MA. Knowledge and attitudes of Jordanian nurses towards patients with HIV/AIDS: findings from a nationwide survey. J Mental Health Nurs. 2011; 32: 774-84. http: //dx.doi.org/10.3109/01612840.2011.610562

[3] Akin S, Mendi B, Mendi O, et al. Turkish nursing students' knowledge of and attitudes towards patients with HIV/AIDS. J Clin Nurs 2013; 22(23-24): 3361-71. http://dx.doi.org/10.1111/jocn. 12378

[4] Meena LP, Pandey SK, Rai M, et al. Knowledge, Attitude, and Practices (KAP) study on HIV/AIDS among HIV patients, care givers and general population in north-eastern part of India. J Med Sci Public Health. 2012; 2(1): 36-42. http://dx.doi.org/10.5455/ijmsp h. 2013.2.36-42

[5] Holzemer WL. University of California, San Francisco International Nursing Network for HIV/AIDS Research. International Nursing Review. 2007; 54: 234-42. http://dx.doi.org/10.1111/j.1 466-7657.2007.00571.x

[6] Chendake MB, Mohite VR. Assess the knowledge and attitudes of nursing students towards HIV/AIDS. Indi J. Sci. Res [Internet]. 2013; 4(1):69-4. Available from: https ://www . academia.edu/4905780/ASSESS_THE_KNOWLE DGE_AND_ATTITUDENURSING_STUDENTS_TOWAREDS_HIV_AIDS

[7] Pickles D, King L, Belan I. Attitudes of nursing students towards caring for people with HIV/AIDS: thematic literature review. Journal of Advanced Nursing. 2009; 65(11): 2262-73. http: //dx.doi.o $\mathrm{rg} / 10.1111 / \mathrm{j} .1365-2648.2009 .05128 . \mathrm{x}$

[8] Canadian Association of Nurses in AIDS Care (CANAC), Core Competencies for HIV/AIDS Nursing Education at the Undergraduate Level [Internet] 2013. Available from: http://www. canac .org/ Resources/CANAC_core_comp_e.pdf

[9] Karawita A, Ariyaratna K, Gunathilaka M, et al. Stigma among Healthcare workers against People living with HIV in Sri Lanka. Presented at the 11th ICAAP. Queen Sirikith Convention Center,Bangkok, Thailand. 2013. Available from: http://www.slideshare.net/Dr_ajith_karawita/sri-1 ankan-experience-on-reduction-of-hivstigma-and-dis crimination-among-healthcare-workers

[10] Karawita A, Gunathilaka M, Manathunga A, et al. Welcome to care is an effective HIV stigma reduction intervention for health care workers. Presented at the 11th ICAAP. Queen Sirikith Conventional Centre, Bangkok, Thailand. 2013. Available from: http://www.sl ideshare.net/Dr_ajith_karawita?utm_campaign=Profil etracking\&utm_-=sssite\&utm_source=ssslideview

[11] Williams AB, Wang $H$, Burgess $J$, et al. Effectiveness of an HIV/AIDS educational program for Chinese nurses. Journal of AdvancedNursing. 2006; 53: 710-20. http://dx.doi .org/10.1111 /j.1365-2648.2006.03777.x
[12] Maimaiti N, Shamsuddin K, Abdurahim A, et al. knowledge, Attitude and Practice Regarding HIV/AIDS among University Students in Xinjiang. Global Journal of Health Science. 2010; 2(2): 51-60. http://dx.doi.org/10.5539/gihs.v2n2p51

[13] EL-nady MT, Geamey EM, Ibrahim NE. Student's knowledge, attitudes, and practices towards patients with HIV/AIDS at college of nursing, King Sound University. Med. J. Cairo Univ [Internet]. 2010; 78(2): 93-01

[14] Ouzouni C, Nakakis K. HIV/AIDS Knowledge, attitudes and behaviors of student nurses. Health Science Journal [Internet]. 2012; 6 : 129-50. Available from: http://knakakis . advancednursing.t eiste.gr/wp-content/uploads/2014/01/10.pdf

[15] Barbe JN. Nursing students' knowledge and attitudes towards HIV/AIDS patients. [Honors' Thesis]. [Ochio state]: the Ochio state University; 2005. Available from: http://hdl .handle.net/181 $1 / 555$

[16] McCarthy EA, O'Brien ME, Rodriguez WR. Training and HIVTreatment Scale-Up: Establishing an Implementation Research Agenda. PLoS Med. 2006; 3(7): e304. http://dx.doi.org/10. 1371/journal.pmed.0030304

[17] Bishop GD, Oh HML, Swee HY. Attitudes and beliefs of Singapore health care professionalsconcerning HIV/AIDS. Singapore Medical of Journal [Internet]. 2000; 41(2): 55-63. PMid:11063203

[18] Pisal H, Sutar S, Sastry J, et al. nurses' health education program in India increace HIV knowledge and reduces fear. Journal of the Association of Nurses in AIDS Care. 2007; 18(6): 32-43. http://dx.doi.org/10.1016/j.jana

[19] Wu Z, Detels R, Ji G, et al. Diffusion of HIV/AIDS knowledge, positive attitudes, and behaviors through training of health professionals in China. AIDS Educ Prev [Internet]. 2002; 14(5): 379-90.

[20] Lui PSC, Sarangapany J, Begley K, et al. "Medical and Nursing Students Perceived Knowledge, Attitudes, and Practices concerning Human Immunodeficiency Virus.” ISRN Public Health. 2014; [about 9 pages]. http://dx.doi.org/10.1155/2014/975875

[21] Lohrmann C, Valikaki M, Suominen T, et al. German nursing students' knowledge of and attitudes to HIV and AIDS: two decades after the first AIDS cases. JAN. 2000; 31(3): 696-03. http://dx.d oi.org/10.1046/j.1365-2648.2000.01326.x/full

[22] Peate I, Suominen T, Valimaki M, et al. HIV/AIDS and its impacton student nurses. Nurse Education Today. 2002; 22: 492-01. http://dx.doi.org/10.1054/nedt2002.0747

[23] International Council of Nurses. ICN Cord of ethics for nurses 2006. Geneva, Switzerland: Author.

[24] Relf MV, Laverriere K, Devlin C, et al. Ethical beliefs related to HIV and AIDS among nursing students in South Africa and the United States: Across-sectional analysis. International Journal of Nursing Studies. 2009; 46(11): 1448-56. http://dx.doi.org/10.1016/j . ijnurstu

[25] Jahan HR, Ghaffari M, Tavakoli R, et al. The impact of group discussion and film on promoting knowledge and attitudes about HIV/AIDS in medical university students: A comparing study. World Applied Science Journal. 2009; 6(7): 961-65. http://dx . doi .org/10.1. 1.388. 5642 
[26] HIV curriculum for the health professional: Baylor International Pediatric AIDS Initiative [Internet]. Baylor College of Medicine. Houston, Texas, U.S.A; 2006.

[27] Kohi TW, Portillo CJ, Safe J, et al. The Tanzania HIV/AIDS Nursing Education (THANE) Preservice Curriculum. Journal of the association of Nurses in AIDS care. 2010; 21(2): 92-8. http: $/ / d x$.doi.org/10.1016/j.jana.2009.06.006

[28] PILOT TRAINER'S MANUAL BASED ON Reducing Stigma and Discrimination Related to HIV and AIDS. Training for Health Care Workers (Engender Health, 2004) [Internet]. Kyiv; 2009.

[29] HIV Basic course for nurses: Facilitator's guide [Internet]. Chennai. General Hospital of Thoracic Medicine Tambaram Sanitatorium. 2005.

[30] Mockiene V, Suominen T, Valimaki M, et al. The Impact of Education Intervention to Change Nurses' Knowledge and Attitudes in Lithuania: A Randomized Controlled Trial. Journal of the Association of Nurses in AIDS Care. 2011; 22(2): 140-9. http: $/ /$ dx.doi.org10.1016/j.jana.2010.07.006

[31] Subhan MS. Current pedagogical teaching strategies being used by educators at the Kwazulu National Collage of nursing campuses across varied subjects and their view regarding innovative methodologies [master's dissertation]. [Durban]: Durban University; 2014. Available from: http://ir.dut.ac.za:8080/bitstream/handle/10321/12 62/SUBHAN_2014.pdf? sequence $=1 \&$ isAllowed $=y$

[32] Kamath N,Udayakiran N. Effectiveness of participatory learning activity (PLA) cum lecture method on knowledge of nursing students in HIV/AIDS. IOSR Journal of Nursing and Health Sciences [Internet]. 2014; 3(2): 18-21. Available from: http://iosrjournals.org/iosr-jnhs/papers/v ol3-issue2/Version-5/D03251821.pdf

[33] Sheng WU, Li Li, Zunyou WU, et al. A Brief HIV Stigma Reduction Intervention for Service Providers in China. AIDS Patient Care and STDs. 2008; 22(6): 513-20. http://dx.doi.org/10.1089/apc .2007 .0198

[34] Yiu JW, Mak WWS, Ho WS, et al. Effectiveness of knowledgecontact program in improving nursing students' attitudes and emotional competence in serving people living with HIV/AIDS. 2010; 71(1): 38-44. http://dx.doi.org/10.1016/j.socscimed.2 010.02 .045

[35] Eckstein EC. Knowledge and Attitudes of nurses regarding patient with acquired Immunodeficiency syndrome [A thesis presented to the faculty of the Frances Payne Bolton School of Nursing]. [USA]: Case Western Reverse University; 1987

[36] Delobelle P, Rawlinson JL, Ntuli S, Malatsi I, Decock R, Depoorter A M. HIV/AIDS knowledge, attitudes, practices and perceptions of rural nurses in South Africa. Journal of Advance Nursing. 2009; 65(5):
1061-73. http://dx.doi.org/10.1111/j.1365-2648.2009.0 4973. $\mathrm{x}$

[37] Gutierrez JMM. Assessment of HIV/AIDS educational intervention on stigma reduction among nurses: a quasi-experimental study. International Journal of Advance Nursing Studies. 2014; 3(2): 90-6. http://dx.doi.org/10.14419/ijans.v3i2.3609

[38] Froman RD, Owen SV, Daisy C. Development of a Measure of Attitudes toward Persons with AIDS. Image: the Journal of Nursing Scholarship. 1992; 24(2): 149-52. http://dx.doi .org/10.1111 /j.1547-5069.1992.tb00240.x

[39] Eriksson L. Nursing students' knowledge and attitudes towards people living with HIV/AIDS [Internet]. 2010 [cited 2015 April 20]; 1-50. Available from: http://rkh.diva-portal.org/smash/ get/diva2: 406047/FULLTEXT01.pdf

[40] Froman RD, Owen SV. Measuring attitudes toward persons with AIDS: The AAS-G as an alternate form of the AAS. Sching Nurs Pract [Internet]. 2001; 15(2): 161-74.

[41] Froman RD, Owen SV. Further validation of the AIDS attitude scale. Research in Nursing and Health. 1997; 20 (2): 161-7. 4

[42] Gagnon M, Cator S. Mapping HIV nursing Core Competencies in Entry-level Education: A Pilot Project. Journal of Nursing Education. 2015; 54(7): 409-15. http://dx.doi.org/10.3928/01484 834-20150617-12

[43] National AIDS Control Programme, Ministry of Health Sri Lanka Statistics from the National STD/AIDS control program [Internet] 2013. Available from: http://www.aidscontrol.gov.lk/web /images/pdf/Annual\%20report\%20of\%20NSACP\%202013.pdf

[44] Sabane HH, Dixit RR, Durge PM. Impact of knowledge about post exposure prophylaxis among nursing students. Health line Journal of Indian Association of Preventive and Social Medicine [Internet]. 2011; 2: 27-31. Avilable from: http://www.iapsmgc.org/oa3v2i1

[45] Dixit S, Khatri AK, Taneja G, et al. Impact of Educational Intervention Measures on Knowledge regarding HIV/ Occupational Exposure and Post Exposure Prophylaxis among Final Year Nursing Students of a Tertiary Care Hospital in Central India. Online J Health Allied Scs [Internet]. 2010; 8(4): 6. Available from: http://www. ojhas.org/issue32/2009-4-6.htm

[46] Taher E, Abdelhai R. Nurses' knowledge, perceptions, and attitudes towards HIV/AIDS: effects of a health education intervention on two nursing groups in Cairo University, Egypt. J. Public Health Epidemiology [Internet]. 2011; 3(4): 144-54. Available from: http://www.academicjournals.org/journal/J PHE/article-abstract/9E8880A1304

[47] Angel Rajakumari G, Sheela R. knowledge of HIV/AIDS among nursing students. International Journal of Science and Research (IJSR) [Internet]. 2015; 4(5): 578-80. 